\section{出でよ 国宝級の成形芸術}

山田浩二*

熱可塑性プラスチックの射出成形法の登場によって, 人 間の生活は飛躍的に向上した。それは「より軽く,より小 さく, より精密に, より大量に, より安価に」という利点 を最大限に生かしたものであり, その方向性はこれからも 本質的には変化しないであろう。その意味では, 同一規格 で数万個も製造されるプラスチック成形品は, 芸術の世界 からは最も遠いところに位置するように見える。

しかし，本来西洋では芸術（Art）は技術（Technology） と同義であり, 不可分の存在であった. ならば, プラスチッ ク成形品に芸術品としての命を吹き込むことも可能ではな いだろうか. 同じ化学製品でも，たとえば瀻維は，ファッ ションという高い感性が要求される分野との接点を持ち, また合成樹脂を多量に含有する塗料には, 自動車や建築物 などにカラーデザインを施す役割もある。ならば，近い将 来射出成形品にも, 「芸術作品」と呼べるものが生まれて くるのは間違いない.

それはすなわち制作者が意図して創造する, 射出成形に よる芸術品である，その制作には何よりもまず金型が必要 になる．細かな表面加工などの金型技術もさることながら， 第一に固定-可動両型に開閉する必要がある。この絶対的 な制約のもとで金型を作成する作業はそれだけで十分に芸 術的である. 次に成形材料を吟味しなければならない。 そ れは既存の樹脂グレードの中から選択するだけでなく, 制 作者の意図にあった材料を一から製造する必要も出てくる. そしていよいよ実際の成形作業すなわち作品の制作にはい る.ここでも最適な成形機が厳選され, 作品によっては多 色やガスアシストなど様々な成形機が使用される。もちろ ん成形には，それにふさわしい技能を持ったスペシャリス 卜があたる。これは “作品”であるから，制作者は納得す るものが得られるまで試作と破壊を繰り返す。中には, ジェッティングやボイドなどの予期せ女不良現象の発生も ありうるが，これは陶芸でいう「窵変」として逆に珍重さ れるかもしれない．これが芸術の面白いところである.

こうして類まれなるプラスチック射出芸術が確立される。 あるものは高值で取引され，特に価值あるものは美術館に 収蔵され，国宝級との評価を受けることだろう。

と，荒唐無稽な初夢に酔ったが，これら一連の作業はま さしくプラスチック製品の製造工程そのものであることに 気づく，言い換えれば，我々の日々の業務は十分に創造的 であり，芸術的である。それを誇りに思いたいものだ.

\footnotetext{
* Yamada, Koji

大阪市立工業研究所 加工技術課 成形加工研究室

大阪市城東区森之宮 1-6-50（５536-8553）
}

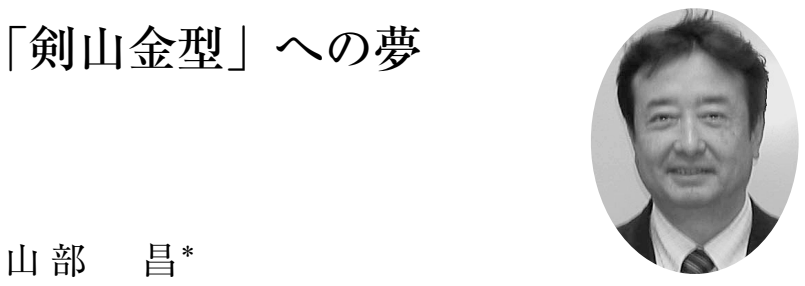

私が日産自動車(株)中央研究所在籍していた頃，当時の工 機工場設計部より研究所に異動され，その後私の上司とな られた野村秀夫氏（現テクノパート社長）は，大変多くの アイデアを持ちの方であった．その中の一つに野村氏命 名「剣山金型」があり，私も彼とともにいまだに夢を見つ づけている.

物づくりの原点は，やはり金型作りと私は考えている. しかし，金型作りに多大な時間や費用がかかっていること は紛れもない事実であり，何とかこれを簡略化し，効率化 できないかというニーズからこの「剣山金型」は生まれた。

原理は生け花で花を固定する，まさに「剣山」である。 但し針の先端は平面となっており，いわば四角柱の棒を多 数束ねたと扔考えいただきたい。この四角柱の剣山針は， あるときはそれぞれ独立にスライドすることが可能である し，また固定することも可能である. たとえば, CAD デー 夕を用いてクレイ (粘土) モデルを作成したとする。この ときこの剣山金型をこのクレイモデルにゆっくりと押し当 てると，四角柱の針は粘土面に沿ってスライドする，その 後針を固定してクレイモデルを取り除くと，部品の反転し た形状面が得られるというアイデアである。複雑な局面を 有する場合は，さらに微小な四角柱針を束ねることにより， 容易に形状の転写が可能となる。この状態で，射出成形な らゲートを追加し，この金型を成形機内に何らかの方法で 固定すれば，成形はいとも簡単に実現することになる。原 理的に言って製品面は多少の凸凹は生ずるが，例えば意匠 面ではない面には十分に可能と考える。 また，試作品を取 得するレベルであれば，簡易で安価に製作することができ るのではないだろうか？

当然成形が終了したら，この金型は針の固定を解き，四 角柱の針をメンテナンスすれば，何度でもリサイクル可能 である。

CAD データからクレイモデルを作らずに，加工ロボッ トがこの針を形状デー夕通りにスライドさせることも容易 に可能であろう。それが実現できれば，クレイモデルや基 型を作成することも省略して，直接金型を作成することも できる.

このように長年「剣山金型」の夢を膨らませているわけ であるが，夢から現実に引き戻されるのが，「冷却」の課 題であろうか. プラスチック成形用金型は一種の熱交換器 である。この熱を奪うという機能をこの剣山針になんとか 付与することは出来ないものだろうか？まだまだ夢を見つ づければと願っている。

\footnotetext{
* Yamabe, Masashi

金沢工業大学 高度材料科学研究開発センター

松任市八束穂 3-1 石川リサーチパーク内（９924-0838）
} 